\title{
DETERMINANT OF CUSTOMER TRUST ON E-COMMERCE AND ITS IMPACT TO PURCHASE AND WORD OF MOUTH INTENTION: A CASE OF INDONESIA
}

\author{
Achmad Nizar Hidayanto, Arfian Herbowo, \\ Nur Fitriah Ayuning Budi and Yudho Giri Sucahyo \\ Faculty of Computer Science, Universitas Indonesia, Depok, Indonesia
}

Received 2014-08-18; Revised 2014-10-05; Accepted 2014-10-29

\begin{abstract}
Even though e-commerce business grows rapidly, still building customer trust on e-commerce becomes more difficult than building customer trust on physical store. This study aims to identify factors that influence customer trust on e-commerce, to compare how important those factors in influencing customer trust and furthermore, to assess how important customer trust for purchase and word of mouth intention. This study combines TOE (Technology, Organizational and Environment) and TPE (Technology, Personal and Environment) framework as reference models used in hypotheses modeling. This research uses quantitative study by conducting survey and accordingly distributing questionnaires to e-commerce users, thus obtaining 151 respondents. The result of this study showed the most essential factors that influence customer trust on e-commerce are web quality and vendor image. This study also revealed that customer trust has positive and significant impact to customer intention to purchase and word of mouth intention.
\end{abstract}

Keyword: E-Commerce, Personal, Technology, Organization, Environment, TOE Framework, TPE Framework, Trust, Word of Mouth

\section{INTRODUCTION}

It has been long time ago since Indonesia is famous as potential country to perform commercial business due to its strategic position geographically. Besides, Indonesia has relatively stable economic growth and considered to be the highest in the world. Further, because of the wide market potential, there are many entrepreneur and businessman starting up a business in Indonesia. This situation increases the competition that leads them to think a creative way by making better innovation for their products or services offered, as well as for the process model performed.

Rapid and continuous growth of internet utilization has fostered the emergence of e-commerce. Accordingly, e-commerce looks promising for most businessmen in Indonesia. Therefore, e-commerce offers potential growth to gain customer for now and future. According to Nemat (2011), e-commerce is the use of internet and website to perform a business transaction. In other words, e-commerce is a business performed via modern information technology, internet. E-commerce business in Indonesia is various, for example some of the wellknown and credible e-commerce business is bhinneka.com, lazada.co.id, dinomarket.com, blibli.com, erafone.com, tokobagus.com, berniaga.com and so on. Nowadays, e-commerce business developed by Small Medium Enterprises (SMEs) is starting up.

Despite its potential benefit of e-commerce, there is a remained obstacle faced by e-commerce business for so Corresponding Author: Achmad Nizar Hidayanto, Faculty of Computer Science, Universitas Indonesia, Depok, Indonesia 
long. It is how to be successful to gain a loyal customer. Keaveney (1995) denotes it is more difficult and less efficient to get a customer compare to retain and maintain them, which the cost to gain a new customer will be five times bigger than the cost to retain a customer (D'Ambra and Xiao, 2010). Another study by Reichheld and Schefter implies if a company could retain a customer for 5\%, thereby increasing profit for $25-95 \%$. Thus, it is important to build a strategy for customer retention for company sustainability (D’Ambra and Xiao, 2010).

An essential key to gain a loyal customer is by building customer trust. A study by Mayer et al. (1995) defines trust as an expression to accept the opponent's belief (Kim and Park, 2012). In addition, Doney and Cannon stated trust is someone's belief to others (Kim and Park, 2012). Accordingly, trust is accentuated as a main factor determines customer loyalty from many literatures (D'Ambra and Xiao, 2010).

Building customer trust on e-commerce would be more difficult because this kind of business model might not provide a physical store that could be touched and felt by customers directly. For this purpose, this study aims to identify determinant factors that influence customer trust on e-commerce, to compare how important those factors to influence customer trust and further to assess how important customer trust for improving purchase intention and word of mouth.

\section{LITERATURE REVIEW}

\subsection{Electronic Commerce}

Electronic commerce (e-commerce) has various definitions. According to Nemat (2011), e-commerce is the use of internet and website to perform business transactions. Therefore, e-commerce is kind of business model performed using modern technology and systems via internet as fundamental support. Because it is performed via wide network; e-commerce supports total ubiquity, so that all users are possible to have the transactions anywhere and any when as long as connected to the internet.

However, according to Bhattacherjee (2002), if we compare to the traditional retailer store "brick and mortar", e-vendor loses some advantages, like physical closeness and intimacy with customers, as well as lack of customer awareness and trust. Friedman et al. (2000) implies e-commerce presents a complex mixture between human character and technology (He, 2011). Thus, initiation, building and retaining customer trust generally become a key to be success in this kind of business model for e-vendor (He, 2011).

\subsection{Trust}

Beldad, Jong and Steehouder define trust as an expectation from an interaction and belief related to weakness exposure and acceptance (Kim and Park, 2012). In sociology, Das and Teng accentuate trust as institutional aspects (Kim and Park, 2012). Another study by Moorman, Zaltman and Deshpande define trust as a dependency to the adversaries or partners with an expectation their words is reliable (Kim and Park, 2012). Further, trust is emphasized as a main factor determines customer loyalty from many literatures (D'Ambra and Xiao, 2010).

According to Lewis and Weigert, trust has two fundamental characteristics that is cognitive and emotional, that is represented by social experience (Kim and Park, 2012). Moorman et al. (1992) denotes cognitive trust is the extension of what customers believe to a certain thing or desire to depend on capability and consistency of service provider (Kim and Park, 2012). In general, an individual creates a cognitive trust outweigh their expectation resulted from interpersonal relationship based on their psychological status. This cognitive trust covers three dimensions; they are integrity, benevolence and competence (Kim and Park, 2012).

Rempel et al. (2002), Holmes and Zanna refer emotional trust as customer belief about a company based on emotional feeling they feel from company's attention to the customers (Kim and Park, 2012). Cognitive trust is accumulated from direct observation by customer toward company actions and services, whereas emotional trust is a concept shaped during emotional relationship between customers and the company (Kim and Park, 2012). Stated cognitive trust is the basic of emotional trust (Kim and Park, 2012).

\subsection{Technology, Organization, Envronment (TOE) Framework}

Technology, Organization, Environment (TOE) framework is developed for innovation adoption (Tornatzky and Fleischer, 1990; Scott, 2007). The technological context presents an internal and external technology for an organization, covering the current practice and appliances and the availability of external technology (Starbuck, 1976). Then, the organization context presents descriptive assessment upon the organization, particularly related to the organization business coverage, management structure and organization size. The environmental context shows the organization business areas, including industry, competitors, relationship and government policy (Tornatzky and Fleischer, 1990). 
TOE framework has been used widely by many researchers. Information systems researchers use TOE framework to analyze Electronic Data Interchange (EDI), open systems and e-business adoption (Scott, 2007). Later on, TOE framework has been adopted for information technology study to provide analysis framework to be used for studying different adoption and assimilation of IT innovation.

\subsection{Technology, Personal, Envronment (TPE) Framework}

TOE framework explains about technological acceptance within an organization. It integrates technological, organizational and environmental factor, so that provide comprehensive model to be used. However, TOE is designed for organizational context, which organizational factor is considered explicitly, but not for individual context. Therefore, Jiang et al. (2010) developed a derived model of TOE framework to investigate the influence of technology, personal and environment factor for individual acceptance that is called Technology, Personal, Environment (TPE) framework. Even though TPE and TOE framework look similar, TPE variables must be adjusted for individual level. Technological context has variables such as self-efficacy, technical needs, perceived usefulness and perceived ease of use. Personal context covers individual characteristics, such as openness, compatibility and risk avoidance. Environmental context comprises of social factors and institutional factors.

\section{RESEARCH MODEL AND HYPOTHESES}

Foundation of this study is about customer trust to ecommerce business. To analyze customer trust on ecommerce, it could be grouped into three aspects, i.e., factors that influence customer trust, trust and impact the trust to organizational performance. The following explanation presents research hypotheses and Fig. 1 presents research model of this study.

\subsection{Technological Context}

\subsubsection{Web Quality}

Web quality design plays important role to attract, gain and retain customers. A high quality website not only determines customer decision to purchase, but also becomes a main reason whether a customer will purchase online or not (Liao et al., 2006). Low quality of website could impact on customer lost, cost escalation and profit reduction. Therefore, it is important to know how web quality impact on customer trust of the website, that eventually determines purchasing decision. Some of web quality elements, they are information quality, response time and visual attraction, impact to what customers perceived (Liao et al., 2006). If customers feel the website has high quality, then they tend to have high trust to seller. They believe the seller has competence, integrity, benevolence and they have willingness to depend to the seller (Liao et al., 2006). Therefore, we propose the hypothesis as follows.
Hypothesis H1 = Web quality perceived by users has positive impact to customer trust on e- commerce

\subsubsection{Privacy and Security}

Privacy refers to customer perception related to possibility of the seller to protect and safeguard confidential information of the customers during the electronic transaction made (Kim et al., 2008). During the transaction, online seller collects name, email, telephone number and address of the buyer. In this case, there is possibility of some sellers to give those confidential; information to the spammers, telemarketers and mailers directly. This illegal action could endanger the customers in any way, for example spamming the counterfeit claim of credit card or any kind of customer identity stealing. Because of this purpose, information protection and security become serious concern and important for many buyers.

Security refers to the customer perception that internet vendor will meet security requirement such as authentication, integrity, encryption and non-repudiation (Kim et al., 2008). How customers see the information security protection during online transaction depends on how they understand about security level implemented by the seller. When customers find security features (for example security policy, disclaimer, security guarantees, etc.) and protection mechanism on seller's website, they could know and perceive that there is an intention of seller to safeguard their information during online transaction (Kim et al., 2008). Consequently, customer perception about security protection increases customer trust to the vendor and also decreases the risks perceived by customers to make a transaction. Therefore, we propose the hypothesis as follows.
Hypothesis H2 = Privacy and security perceived by users has positive impact to customer trust on e-commerce.




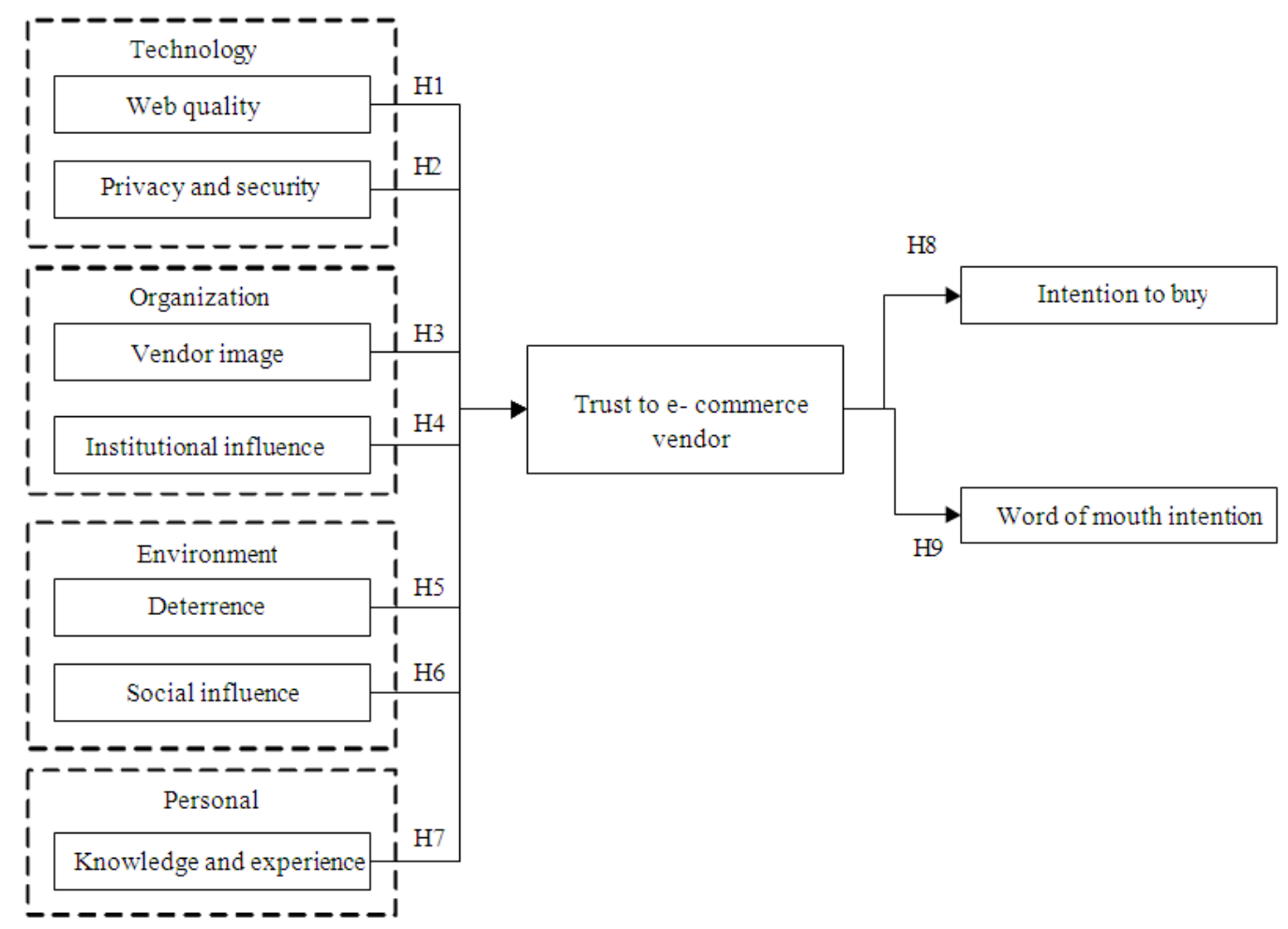

Fig. 1. Research model

\subsection{Organizational Context}

\subsubsection{Vendor Image}

The standard of vendor image could be analyzed from vendor reputation, company scale and product choices (He, 2011). Koufaris and Hampton-Sosa (2004) denotes customer perception to the e-commerce site plays as main role to build customer trust of that site. Thus, e-vendors should foster good reputation for their own good to increase customer trust. Previous studies have presented positive correlation between vendor reputation and customer trust (Kim and Park, 2012). Customers tend to consider company reputation as the essential factor before they put their trust when they are going to purchase a product or service. Related to company scale, a big company is likely to provide more diverse and various products and services to customers on their e-commerce website. It shows that customer perception on company scale could impact customer trust building in an organization or company. Therefore, we propose the hypothesis as follows.

Hypothesis $\mathrm{H} 3$ = Vendor image perceived by users has positive impact to customer trust on e-commerce

\subsubsection{Instritutional Influence}

There are two dimension of institution-based trust; they are structural assurance and situational normality (McKnight et al., 2002). Structural assurance is one's belief that a structure, such as guarantee, regulation, promise, legal initiative, or other procedures, is place rightly to achieve a success. For example, someone with high web-related structural assurance will feel convinced that the laws and technological protection, such as data encryption will safeguard them from losing their privacy, confidentiality, identity, or money. Situational normality refers one's belief that environment will be appropriate and success if the situation runs normally as expected. Customers who feel high situational normality would believe that the environment on internet is appropriate, well ordered and favorable to perform personal business. They would believe that internet vendors have competence, benevolence and integrity. Therefore, we propose the hypothesis as follows.
Hypothesis H4 = Institutional influence perceived by users has positive impact to customer trust on e-commerce




\subsection{Environmental Context}

\subsubsection{Deterrence}

According to Shapiro et al. (1992) deterrence is under lied the assumption that rational person would not involve in any kind of opportunistic behavior or action that they could lose one's trust (He, 2011). Thereby, an individual could calculate the consequences of other's fraudulence or make cooperation with them and build an image if they could be trusted or not. For example of deterrence-based trust are calculative trust and legal framework. According to Williamson (1993), trust is viewed as rational calculation of individual benefit (He, 2011). In the context of e-commerce, Gefen stated that customers would trust an e-vendor, if customers believe the e-vendors would lose more if they are dishonest and would get nothing because they break the customer trust (He, 2011).

Meanwhile, Connolly and Bannister (2007) stated that legal framework refers to the regulations and laws enforcement of online transactions (He, 2011). Customers tend to believe an e-vendor if they believe the existing laws and regulations are sufficient to safeguard their business. An e-vendor is impossible to conduct criminal actions because they are afraid of the severe punishment. Therefore, we propose the hypothesis as follows.

Hypothesis H5 = Deterrence has positive impact to customer trust on e-commerce

\subsubsection{Social Influence}

Differ from the economist opinion that human behavior is likely the result of the individual rationality and interest, the sociologist emphasizes human behavior is related to social relationship (Granovetter, 1985). One's action is limited by 'the concrete', continuous systems of social relationship, such as social networking, culture, politics and religion. In e-commerce related study, social norms, customer reviews and friend's recommendations have been studied as the important social factors that have contribution in building customer trust (He, 2011). Therefore, we propose the hypothesis as follows.

Hypothesis H6 = Social influence has positive impact to customer trust on e-commerce

\subsection{Personal Context}

\subsubsection{Knowledge and Experience}

Human capital model empowers customer knowledge as human capital that influences information and price searching. Human capital is gained and developed through formal and informal education, trainings, seminars, or learning by doing. A term related to human capital is self-efficacy that is defined as a belief of human capability to perform an action, which is influenced by various sources of information either from direct or indirect experiences (He, 2011). In the context of e-commerce, Gefen stated that the more knowledge and experience someone gets from a website, the more trust could be build toward the website (He, 2011). Therefore, we propose the hypothesis as follows.
Hypothesis H7 = Customer knowledge and experience have positive impact to customer trust on e-commerce

\subsection{Trust to Ecommerce Vendor}

\subsubsection{Purchase Intention}

Doney and Cannon imply customer trust to a seller leads the purchase decision and becomes the main factor that influences intention to buy (Kim and Park, 2012). Further, study by Jang investigated the impact of customer trust on internet shopping and found a significant correlation between customer trust and customer intention to buy (Kim and Park, 2012)Another study by Kuan and Bock proposed the same finding that customer trust on e-commerce has positive impact to customers to purchase a product online (Kim and Park, 2012). Therefore, we propose the hypothesis as follows.
Hipotesis $\mathrm{H} 8$ = Customer trust has positive impact to customer intention to buy online on e- commerce site

\subsubsection{Word of Mouth Intention}

Another dimension of customer trust performance is Word Of Mouth (WOM) intention. In this study, WOM intention refers to which extent customers are willing to exchange positive and negative evaluation of a product or service based on direct or indirect experience to the other customers (Hong and Yang, 2009). Kim and Kim suggested customer trust is a prerequisite of WOM intention both online and offline (Kim and Park, 2012). Internet users interact actively each other and many users are influenced by other's opinions and experiences of a product or service. Thus, buyers with high trust to ecommerce seller tend to share their experience or other related information online to others, such as site reputation, vendor reputation, customer service level and level of trust (Kim and Park, 2012). Consequently, customer trust directly influences word of mouth intention. Therefore, we propose the hypothesis as follows. 
Hipotesis $\mathrm{H} 9=$ Customer trust has positive impact to word of mouth intention on ecommerce site

\section{METHODOLOGY}

\subsection{Sample and Data Collection}

Population of this study is all users of e-commerce Business to Consumer (B2C) in Indonesia. The user encompasses all people who has ever accessed or used ecommerce sites, either for buying a product, comparing product prices, or just searching product information. If they only know the sites, but they have not yet used or accessed, they will be excluded from the population. Total sample suggested for using SEM (Structural Equation Modeling) technique is $100-150$ samples. Within a month, it had been collected 151 sample data and it considered enough to be processed using SEM technique.

The questionnaire was created using Gdocs, so that the questionnaire handed out online for the efficiency purpose. In this case, the questionnaire had been distributed via email, social network such as Facebook, Twitter and online forum Kaskus as the largest ecommerce site in Indonesia. In order to validate the respondent criteria set up, before the respondents filled up the questionnaire, they were asked a question if they have ever used e-commerce site. If they have not yet, they need not to fill up the questionnaire.

\subsection{Research Instrument}

Research instrument was derived in accordance with several references and literatures. The measurement scale of the questionnaire uses five-point Likert scale to know the degree of respondent conformity, they are 'strongly agree' (5), 'agree' (4), 'neutral' (3), 'disagree' (2), 'strongly disagree' (1).

The questionnaire consists of two parts. The first part represents respondent demography such as gender, age, occupation, education, monthly income, favourite sites, media access, purchase frequency, internet usage, spending level and favourite products to purchase. The second elaborates the indicators that will be analyzed and examined to determinant factors that influence customer trust on e-commerce and further to assess how important customer trust for organizational performance.

We conducted readability test to assess if the questionnaire is understandable and readable by the respondents before the questionnaires were distributed. The total sample of readability test is five respondents who have different disciplines. The responses, suggestions and critics were examined and revised if there is ambiguity or confusing part in the questionnaire. Based on readability test, some indicators were revised by changing the sentence without changing the meaning as presented in Appendix. After all, the questionnaires were handed out to the respondents for data collection.

\section{RESULT AND DISCUSSION}

\subsection{Respondent Demographic}

Total sample is 151 respondents and respondent profiles are summarized in Table 1, encompasses gender, age, occupation, education, monthly income, favourite sites, media access, purchase frequency, internet usage, spending level and favourite products to purchase.Respondents of this research are varying from private sector employee, public/civil servant, entrepreneur, student, freelance and unemployed who have ever used E-commerce sites. However, mostly respondent of this study is student (55\%), with most of the respondent in the age of between 18-24 years old (71\%). It means that online purchasing becomes a favorite for many students. As listed in Table 1, it is eminently presented that $63 \%$ respondents purchase a product 1-5 times a year from E-commerce site and the price of the product they purchased is 200-500 thousand (34\%). Most of users use PC/home computer to access the E-commerce site and make a transaction (87\%).

\subsection{Measurement Model Test}

The approach to analyze the data is by evaluating the measurement model before the structural model. The evaluation of measurement model is aimed to evaluate reliability and validity, while structural model evaluation is made to evaluate research hypotheses and model fitness. Data analysis is performed by SEM (Structural Equation Modeling) technique using AMOS software. The multivariate normality of data has been tested before SEM processing.

Measurement model test consists of validity and reliability test. The result of measurement model test of this study is presented in Table 2. Validity test evaluates each single question and the result is presented in R-Calculation, then it will be compared with R-Table. R-Table is derived by df (degree of freedom. Total respondent of this study is 151 respondents. By having this number, we know df value is 149 and significance level is $5 \%$, the R-Table is 0.159 . Therefore, if R-Calculation value is below 0.159 , then the indicator is not valid. 
Table 1. Respondent demographic

\begin{tabular}{|c|c|c|c|}
\hline \multicolumn{2}{|l|}{ Gender } & \multicolumn{2}{|l|}{ Occupation } \\
\hline Female & $38 \%$ & & \\
\hline \multirow{8}{*}{ Male } & $62 \%$ & & \\
\hline & & Private sector employee & $17 \%$ \\
\hline & & Public/civil servant & $4 \%$ \\
\hline & & Entrepreneur & $11 \%$ \\
\hline & & Student & $55 \%$ \\
\hline & & Freelance & $2 \%$ \\
\hline & & Unemployed & $3 \%$ \\
\hline & & Others & $8 \%$ \\
\hline \multicolumn{4}{|l|}{ Age (years) } \\
\hline$<18$ & $5 \%$ & & \\
\hline $18-24$ & $71 \%$ & & \\
\hline $25-30$ & $20 \%$ & & \\
\hline $31-35$ & $2.60 \%$ & & \\
\hline$>35$ & $1.40 \%$ & & \\
\hline \multirow[t]{2}{*}{ Education } & & Monthly Income Level (IDR) & \\
\hline & & $<1 \mathrm{Mi}$ & $40 \%$ \\
\hline High school & $15 \%$ & $1-2$ Mio & $24 \%$ \\
\hline Diploma & $11 \%$ & $2-4$ Mio & $22 \%$ \\
\hline Bachelor (S1) & $70 \%$ & 4- 6 Mio & $7 \%$ \\
\hline Master (S2) & $3 \%$ & $6-10$ Mio & $3 \%$ \\
\hline \multirow[t]{2}{*}{ Doctor (S3) } & $1 \%$ & $10-15$ Mio & $2 \%$ \\
\hline & & $>=15$ Mio & $2 \%$ \\
\hline \multirow[t]{2}{*}{ Media } & & Spending Level (IDR) & \\
\hline & & $<100$ thousand & $7 \%$ \\
\hline Home computer & $87 \%$ & $100-200$ thousand & $28 \%$ \\
\hline Internet station & $1 \%$ & 200-500 thousand & $34 \%$ \\
\hline Hand phone & $9 \%$ & 500-1 Mio & $13 \%$ \\
\hline \multirow[t]{2}{*}{ Tablet } & $4 \%$ & 1-3 Mio & $14 \%$ \\
\hline & & $>=3$ Mio & $3 \%$ \\
\hline \multicolumn{2}{|c|}{ Purchase Frequency in last a year } & Internet Usage & \\
\hline Never & $6 \%$ & $<6$ months & $0 \%$ \\
\hline $1-5$ & $63 \%$ & 6-12 months & $1 \%$ \\
\hline $5-10$ & $19 \%$ & $1-2$ years & $1 \%$ \\
\hline $11-15$ & $3 \%$ & 3-4 years & $11 \%$ \\
\hline $16-20$ & $1 \%$ & $5-7$ years & $30 \%$ \\
\hline$>20$ & $8 \%$ & $>7$ years & $58 \%$ \\
\hline
\end{tabular}

Convergent validity test resulted four of 45 indicators that have loading factor value below 0.5 . They are PS1 (0.228), PS2 (0.313), SI6 (0.476) and PI2 (0.456). Because those indicators have loading factor value below 0.5 , then they were eliminated. After the elimination of invalid indicators, each variable fulfills the prerequisite that is having minimum two indicators. Finally, all indicators were re-tested and the loading factor values of all variables are higher than 0.5 .

Reliability test is performed by assessing Cronbach's Alpha (CA) value. For CA value, a good scale of CA should satisfy $\geq 0.7$ for all indicators. The result of reliability test of e-commerce indicators has overall value of 0.962 , which means it has absolute reliability. For this reason, we can concede all indicators have a good validity and reliability scale.

\subsection{Structural Model Test}

The examination of the structural model test is conceived by examining model fitness using path analysis. The result of goodness of fit test of research model results Chi-square (CIMN) value of 71.923, which means proposed model is fit as CIMN value closer to 0 . Besides, fitness value of model could be assessed by looking Normed Chi Square $(1<\mathrm{NC}<5)$, that is 4.794 and also the value of GFI, AGFI, PGFI (closer to 1), that is consecutively $0.899 ; 0.930$; and 0.845 . Further, RMR value of the proposed model also has a value closer to 0 , which is 0.034 , as well as the value of NFI, RFI, IFI and CFI that has a value closer to 1 , that is consecutively $0.904 ; 0.811 ; 0.922$; and 0.919 . 
Table 2. R-calculation, loading factor and alpha values

\begin{tabular}{|c|c|c|c|c|}
\hline Variable Name & Code & R-calculation $(>0.159)$ & Loading factor & Cronbanch's alpha value \\
\hline \multirow[t]{5}{*}{ Web Quality (WQ) } & WQ1 & 0,698 & 0.756 & 0,961 \\
\hline & WQ2 & 0,721 & 0.813 & 0,961 \\
\hline & WQ3 & 0,681 & 0.777 & 0,961 \\
\hline & WQ4 & 0,636 & 0.748 & 0,961 \\
\hline & WQ5 & 0,708 & 0.801 & 0,961 \\
\hline \multirow[t]{6}{*}{ Privacy and Security (PS) } & PS1 & 0,348 & 0.338 & 0,963 \\
\hline & PS3 & 0,414 & 0.54 & 0,963 \\
\hline & PS4 & 0,601 & 0.592 & 0,962 \\
\hline & PS5 & 0,672 & 0.753 & 0,961 \\
\hline & PS6 & 0,641 & 0.793 & 0,961 \\
\hline & PS7 & 0,561 & 0.508 & 0,962 \\
\hline \multirow[t]{4}{*}{ Vendor Image (VI) } & VI1 & 0,737 & 0.789 & 0,961 \\
\hline & VI2 & 0,770 & 0.866 & 0,961 \\
\hline & VI3 & 0,659 & 0.716 & 0,961 \\
\hline & VI4 & 0,674 & 0.678 & 0,961 \\
\hline \multirow[t]{6}{*}{ Institutional Influence (II) } & II1 & 0,598 & 0.759 & 0,962 \\
\hline & II 2 & 0,564 & 0.733 & 0,962 \\
\hline & II3 & 0,548 & 0.757 & 0,962 \\
\hline & II 4 & 0,690 & 0.713 & 0,961 \\
\hline & II5 & 0,655 & 0.810 & 0,961 \\
\hline & II6 & 0,720 & 0.776 & 0,961 \\
\hline \multirow[t]{3}{*}{ Deterrence (DE) } & DE1 & 0,423 & 0.642 & 0,962 \\
\hline & DE2 & 0,478 & 0.625 & 0,963 \\
\hline & DE3 & 0,456 & 0.792 & 0,963 \\
\hline \multirow[t]{5}{*}{ Social Influence (SI) } & SI1 & 0,609 & 0.827 & 0,962 \\
\hline & SI2 & 0,596 & 0.727 & 0,962 \\
\hline & SI3 & 0,623 & 0.841 & 0,962 \\
\hline & SI4 & 0,670 & 0.703 & 0,961 \\
\hline & SI5 & 0,595 & 0.558 & 0,962 \\
\hline \multirow[t]{4}{*}{ Knowledge and Experience (KE) } & KE1 & 0,671 & 0.649 & 0,961 \\
\hline & KE2 & 0,512 & 0.670 & 0,962 \\
\hline & KE3 & 0,534 & 0.865 & 0,962 \\
\hline & KE4 & 0,539 & 0.843 & 0,962 \\
\hline \multirow[t]{4}{*}{ Trust in E-vendor $(\mathrm{T})$} & $\mathrm{T} 1$ & 0,733 & 0.741 & 0,961 \\
\hline & $\mathrm{T} 2$ & 0,750 & 0.804 & 0,961 \\
\hline & T3 & 0,718 & 0.746 & 0,961 \\
\hline & $\mathrm{T} 4$ & 0,735 & 0.786 & 0,961 \\
\hline \multirow[t]{3}{*}{ Word Of Mouth intention (WOM) } & WM1 & 0,757 & 0.968 & 0,961 \\
\hline & WM2 & 0,732 & 0.874 & 0,961 \\
\hline & WM3 & 0,727 & 0.832 & 0,961 \\
\hline \multirow[t]{2}{*}{ Purchase Intention (PI) } & PI1 & 0,776 & 0.847 & 0,961 \\
\hline & PI3 & 0,684 & 0.660 & 0,961 \\
\hline
\end{tabular}

Therefore, we can conclude the proposed model is considered fit and proper to evaluate and analyze the data, as well as ready to continue the next step of structural model test.

The next step of structural model test is conceived by examining $\mathrm{T}$-value to determine the conformity and significance level of hypotheses proposed. Likewise, the significance value depicts the correlation between latent variables. A latent variable has significant correlation with other latent variables if $\mathrm{T}$-value $\geq 1.96$ in significance level
0.05 ; or have path coefficient value $>0.1$. Table 3 summarizes $\mathrm{T}$-value value for each latent variable.

The result of hypotheses test presented on Table 3 shows four out of nine tested hypotheses are accepted, while five other hypotheses are rejected. The five hypotheses which are Privacy and Security (PS), Institutional Influence (II), Deterrence (DE), Social influence (SI) and Knowledge and Experience (KE) have T-statistic value $<1.96$ which means there is no significant correlation to customer trust on e-commerce. 
Table 3. Result of structural model test

\begin{tabular}{|c|c|c|c|c|}
\hline Hypothesis & Path & $\mathrm{T}$ value $(\geq 1.96)$ & Significant/not significant & Conclusion \\
\hline $\mathrm{H} 1$ & $\mathrm{~T} \leftarrow \mathrm{WQ}$ & 2.698 & Significant & Hypothesis accepted \\
\hline $\mathrm{H} 2$ & $\mathrm{~T} \leftarrow \mathrm{PS}$ & 0.630 & Not significant & Hypothesis rejected \\
\hline H3 & $\mathrm{T} \leftarrow \mathrm{VI}$ & 9.227 & Significant & Hypothesis accepted \\
\hline $\mathrm{H} 4$ & $\mathrm{~T} \leftarrow \mathrm{II}$ & -0.368 & Not significant & Hypothesis rejected \\
\hline H5 & $\mathrm{T} \leftarrow \mathrm{DE}$ & -0.763 & Not significant & Hypothesis rejected \\
\hline H6 & $\mathrm{T} \leftarrow \mathrm{SI}$ & 0.945 & Not significant & Hypothesis rejected \\
\hline H7 & $\mathrm{T} \leftarrow \mathrm{KE}$ & 0.324 & Not significant & Hypothesis rejected \\
\hline H8 & $\mathrm{PI} \leftarrow \mathrm{T}$ & 10.227 & Significant & Hypothesis accepted \\
\hline H9 & $\mathrm{WM} \leftarrow \mathrm{T}$ & 11.080 & Significant & Hypothesis accepted \\
\hline
\end{tabular}

Regarding to technological factors, variable Web Quality (WQ) shows significant impact to improve customer trust on e-commerce, but not for variable Privacy and Security (PS) that has no influence to improve customer trust. Further analysis of organizational factors, only variable Vendor Image (VI) presents positive and significant correlation in building customer trust on e-commerce, while variable Institutional Influence (II) has no influence to boost up customer trust. However, the analysis of environmental and personal factors (Deterrence (DE), Social Influence (SI) and Knowledge and Experience (KE)) proved not to impact customer trust improvement on e-commerce. In accordance to the result, the final analysis presents performance of customer trust. Improvement on customer trust brings positive impact for e-commerce vendor by improving Purchase Intention (PI) and Word of Mouth intention (WM) of customers.

\subsection{Discussion}

This study investigates various characteristics of ecommerce that impact to customer trust and also the impact of customer trust to the performance of trust itself. Object of this study is the customers of ecommerce sites in Indonesia. In this study, e-commerce characteristics used to be analyzed is web quality, privacy and security, institutional influence, deterrence, social influence, vendor image and knowledge and experience of customers. Meanwhile, to analyze the performance of trust itself, we use variable of customer intention to purchase/buy and word of mouth intention.

The result of this study using proposed model implies vendor image and web quality have positive correlation to customer trust on e-commerce. Meanwhile, other factors such as privacy and security, institutional influence, deterrence, social influence and knowledge and experience have no significant correlation to customer trust on e-commerce. The result of this study differs from the study by He (2011). Study by He (2011) presents knowledge and experience, deterrence, web quality, privacy and security, vendor image and institutional influence have significant impact to customer trust on e-commerce, but not for the variable of social influence. Another study by (Kim et al., 2008) shows the influential factors of customer trust on e-commerce are familiarity (part of knowledge and experience), privacy, security, information quality (part of web quality) and reputation (part of vendor image). If the study of $\mathrm{He}$ (2011) results significant correlation of institutional influence, the study of McKnight et al., (2002) has different result that shows institutional influence has no significant correlation to trusting beliefs.

If we compare this study to previous studies, most of the proposed variables of previous studies have significant correlation to customer trust on e-commerce. However, still there is variable that have no significant correlation to customer trust on e-commerce. Basically, for each study does not have to result the same findings because there are another factors that influence the result of the study, such as respondent demographic and data analysis technique.

In this study, there are two variables that have significant correlation to customer trust in e-commerce; they are vendor image and website quality. Vendor image has the highest correlation value. It is proved by the respondent choice to Tokobagus.com as the top choice of e-commerce vendor in Indonesia, followed by Bhinneka.com as the first e-commerce site in Indonesia. Those two e-commerce vendors have a good reputation for customers. In addition, web quality also has positive and significant correlation. It means customers would choose to use e-commerce site that has a good quality and characteristics. Because web quality is the important factor to gain customer trust, consequently, e-vendor should concern and improve some elements of web quality such as user interface design, content quality and specific content in order to get customer trust and loyal customers.

Additionally, the result of this study presents five variables that have no significant correlation to customer trust on e-commerce, they are privacy and security, institutional influence, deterrence, social influence and 
knowledge and experience. Privacy and security and institutional influence have no significant influence due to different context and view of e-commerce users in Indonesia. It is explained by the demographic survey that the most used e-commerce site by customers is Tokobagus. Even if Tokobagus provides facility for electronic payment, it also offers an alternative payment service by Cash On Delivery (COD). This alternative payment service certainly has different context of privacy and security for this study, specifically environmental context of e-commerce website itself. Related to institutional influence and internet vendor, it is likely that the respondents do not consider about the internet quality, as in fact the quality of internet in Indonesia is less reliable and they could understand the situation. Furthermore, as the explanation for deterrence factor or legal aspect, it is most likely customers tend to purchase a product online via e-commerce site not because of the laws and regulations protection, because laws enforcement has not run well yet in Indonesia. Meanwhile, social influence variable has no significant correlation to customer trust because social interaction is not performed directly on e-commerce sites. Last, the variable of knowledge and experience also has no correlation to customer trust because customers likely tend to have different concept, perception, representation and thought to trust on e-commerce business.

\subsection{Implication}

This study is expected to give suggestive contribution and implication for science and online commerce (ecommerce) community. E-commerce vendors can employ the result of this study as an evaluation to improve their website quality and reputation. It is important for them to gain a customer trust which is the foundation for gaining loyal customers.

According to the result of this study, website quality and vendor image have positive and significant impact that could influence customer trust to e-commerce. It is suggested for e-vendor to concern more on those two elements in order to gain and improve customer trust. Other elements of website quality that could be developed more are user interface design, content quality, specific content quality and good technical quality of the website (Liao et al., 2006). Whereas, other elements of vendor image that could be developed more are reputation, size of business and product choices. Customers would give their trust more to e-commerce vendor that has a good reputation, big scale product selling and has various kinds of product.
Further, the final analysis of this study results the determinants variables correlated significantly and variables that are not correlated with customer trust positively to e-commerce business, especially in Indonesia. Those findings could be used to strengthen and undergird the previous theories and studies. Findings that strengthen the theories are those with significant and positive correlation, while findings that undermine the theories are those with insignificant and negative correlation. In fact, the previous studies related to this studies show different and various result. Therefore, the result of this study could be used to enrich research and science study of e-commerce in Indonesia.

\section{CONCLUDING REMARK}

From the seven variables (factors) proposed and analyzed, that us knowledge and experience, deterrence, social influence, web quality, privacy and security, vendor image and institutional influence, only two of them that have positive and significant correlation to customer trust on e-commerce. Based on this study, it is found that web quality and vendor image have the most positive and significant impact to customer trust on ecommerce. Because web quality is the important factor to gain customer trust, consequently, e-vendor should concern and improve some elements of web quality such as user interface design, content quality and specific content in order to get customer trust and loyal customers. Further, vendor image becomes the most significant and determinant factor of customer trust on ecommerce. It is proved by the respondent choice to Tokobagus.com as the top choice of e-commerce vendor in Indonesia, followed by Bhinneka.com as the first ecommerce site in Indonesia. Those two e-commerce vendors have a good reputation for customers. Finally, the further analysis resulted that customer trust has positive and significant impact to customer intention to buy and word of mount intention. It shows once customers believe to an e-commerce vendor, they have an intention to purchase a product or service of that vendor, or even, recommend the vendor to the others. Looking at this opportunity, it is important for online sellers (e-commerce vendors) to gain the trust from their customers or prospect customers.

\section{ACKNOWLEDGEMENT}

We convey our gratitude to Universitas Indonesia for their Hibah Institusi Grant and continuous support particularly to the Directorate of Research and Community Engagement. 


\subsection{Author's Contributions}

All authors equally contributed in this work.

\subsection{Ethics}

This article is original and contains unpublished material. The corresponding author confirms that all of the other authors have read and approved the manuscript and no ethical issues involved.

\section{REFERENCES}

Belanger, F., J. Hiller and W. Smith, 2002. Trustworthiness in electronic commerce: the role of privasi, keamanan and site attributes. J. Strategic Inform. Syst. 11: 245-270. DOI: 10.1016/S09638687(02)00018-5

Bhattacherjee, A., 2002. Individual trust in online firms: Scale development and initial test. J. Manag. Inform. Syst., 1: 211-241.

Connolly, R. and F. Bannister, 2007. Consumer trust in Internet shopping in Ireland: Towards the development of a more effective trust measurement instrument. J. Inform. Technol., 2: 102-118. DOI: 10.1057/palgrave.jit.2000071

D'Ambra, J. and L. Xiao, 2010. An Empirical study of multi-dimensional trust and eloyalty in Ecommerce in China. Proceedings of the AMCIS, (CIS' 10), pp: 62-62.

Friedman, B., J.R.P.H. Khan and D.C. Howe, 2000. Trust online. Komunikasis of the ACM, 12: 34-40. DOI: $10.1145 / 355112.355120$

Granovetter, M., 1985. Economic action and social structure: The problem of embeddedness. Am. J. Sociol., 3: 481-510. DOI: 10.1086/228311

Hajli, M., 2012a. Social Commerce Adoption Model. Proceedings of the UK Academy Conference for Information Systems, (CIS' 12) pp: 16-16.

Hajli, M., 2012b. Social Commerce the Role of Trust. Proceedings of the AMCIS, (CRT' 12), pp: 9-9.

Hasan, L. and E. Abuelrub, 2011. Assessing the quality of web sites. Applied Comput. Inform. 9: 11-29. DOI: 10.1016/j.aci.2009.03.001

He, J., 2011. Understanding the sources and impacts of trust in E-commerce: A meta-analysis. Proceedings of the AMCIS-All Submissions, (AAS’ 11), pp: 142-142.

Hong, S.Y. and S.U. Yang, 2009. Effects of reputation, relational satisfaction and customer-company identification on positive word-of-mouth intentions. J. Public Relat. Res., 21: 381-403. DOI: $10.1080 / 10627260902966433$
Jiang, Y., D. Chen and F. Lai, 2010. TechnologicalPersonal-Environmental (TPE) framework: A conceptual model for technology acceptance at the individual level. J. Int. Technol. Inform. Manag.

Keaveney, S., 1995. Customer switching behaviour in service industries: An exploratory study. J. Market., 59: 71-82.

Kim, D., D. Ferrin and H. Rao, 2008. A trust-based consumer decision-making model in electronic commerce: The role of trust, perceived risk and their antecedents. Decision Support Syst., 44: 544-564. DOI: 10.1016/j.dss.2007.07.001

Kim, J. and H. Park, 2012. Fast nonnegative tensor factorization with an active-set-like method. High Performance Sci. Comput., Springer London.

Koufaris, M. and W. Hampton-Sosa, 2004. The development of initial trust in an online company by new customers. Inform. Manag., 41: 377-397. DOI: 10.1016/j.im.2003.08.004

Liao, C., P. Palvia and H. Lin, 2006. The roles of habit and web site quality in e-commerce. Int. J. Inform. Manag., 26: 469-483. DOI: 10.1016/j.ijinfomgt.2006.09.001

Moorman, C., G. Zaltman and R. Deshpandé. 1992. Relationships between providers and users of market research: The dynamics of trust within and between organizations. J. Market. Res., 29: 314-29.

Mayer, R.C., J.H. Davis and F.D. Schoorman, 1995. An integration model of organizational trust. Acad. Manag. Rev., 20: 709-729. DOI: $10.2307 / 258792$

McKnight, D., V. ChoudHury and C. Kacmar, 2002. Developing and validating trust measures for ecommerce: An integrative typology. Inform. Syst. Res. 13: 334-359. DOI: 10.1287/isre.13.3.334.81

Nemat, R., 2011. Taking a look at different types of ecommerce. World Applied Programm., 1: 100-104.

Rempel, A.W., J.S. Wettlaufer and E.D. Waddington, 2002. Anomalous diffusion of multiple impurity species: predicted implications for the ice-core climate records. J. Geophys. Res. Solid Earth, 107: 2330-2330. DOI: 10.1029/2002JB001857

Scott, J., 2007. An e-transformation study using the technology-organization-environment framework. Proceedings of the Merging Emerging Technologies Processes Institutions Bled Slovenia, (IBS' 07), pp: 55- 55.

Shapiro, D.L., B.H. Sheppard and L. Cheraskin, 1992. Business on a handshake. Negotiation J., 3: 365-377. DOI: 10.1111/j.1571-9979.1992.tb00679.x 
Starbuck, W.H., 1976. Organizations and their environments. Chicago: Rand McNally.

Tornatzky, L.G. and M. Fleischer, 1990. The processes of technological innovation. 1st Edn., University of
Williamson, O.E., 1993. Calculativeness, trust and economic organization. J. Law Econ., 30: 131-145.

Michigan, Lexington Books, ISBN-10: 0669203483, pp: 298.

\section{APPENDIX}

\section{Research Variables and Indicators}

\begin{tabular}{|c|c|c|}
\hline Variable & Indicators & References \\
\hline Web Quality (WQ) & $\begin{array}{l}\text { WQ1. E-commerce site where } \\
\text { I purchase a product, provides } \\
\text { accurate and up to date information } \\
\text { for the product I want to buy. } \\
\text { WQ2. . E-commerce site where I } \\
\text { purchase a product, provides useful } \\
\text { and realiable information for me. } \\
\text { WQ3. . E-commerce site where } \\
\text { I purchase a product, provides sufficient } \\
\text { information for me to make a transaction. } \\
\text { WQ4. E-commerce site I choose, has } \\
\text { an interesting web design. } \\
\text { WQ5. E-commerce site I choose, is easy to } \\
\text { use and help me to find the information I look for. }\end{array}$ & $\begin{array}{l}\text { Hasan and Abuelrub (201 } \\
\text { Kim and Park (2012), } \\
\text { McKnight } \text { et al. (2002) }\end{array}$ \\
\hline Privacy and Security (PS) & $\begin{array}{l}\text { PS1. I am afraid if E-commerce site where } \\
\text { I purchase a product, asks too much } \\
\text { my personal information. } \\
\text { PS2. I am afraid if E-commerce site where } \\
\text { I purchase a product will use my personal } \\
\text { information for any other purpose without my permission. } \\
\text { PS3. I keep my privacy and personal information } \\
\text { during the transaction using e-commerce site to } \\
\text { avoid information stealing. For example, be careful } \\
\text { entering name, address, telephone number, } \\
\text { bank account and credit card number. } \\
\text { PS4. I am aware for the security and transaction } \\
\text { policy in E-commerce site where I purchase a product. } \\
\text { PS5. E-commerce site manager implements security } \\
\text { actions to protect online customers. } \\
\text { PS6. E-commerce site manager guarantees the transaction } \\
\text { information will be protected and safeguarded from any } \\
\text { cybercrime action during the transaction process on internet. } \\
\text { PS7. I feel protected and safeguarded in using electronic } \\
\text { payment systems in the e-commerce site where I buy a product. }\end{array}$ & $\begin{array}{l}\text { Kim et al. (2008), } \\
\text { Belanger et al. (2002) }\end{array}$ \\
\hline Vendor Image (VI) & $\begin{array}{l}\text { VI1. E-commerce site where I purchase a product is } \\
\text { well-known and respectable for me and others. } \\
\text { VI2. E-commerce site where I purchase a product is } \\
\text { reputable and trust-worthy. } \\
\text { VI3. E-commerce site where I purchase a product is a } \\
\text { big company that is capable to supply a product in } \\
\text { great number and becomes a big player in the market. } \\
\text { VI4. E-commerce site where I purchase has vary product. }\end{array}$ & $\begin{array}{l}\text { He (2011), } \\
\text { Kim and Park (2012) }\end{array}$ \\
\hline Institutional Influence (II) & $\begin{array}{l}\text { II1. Internet has enough protection and security } \\
\text { systems to ensure secure online transaction } \\
\text { conducted in E-commerce site. } \\
\text { II2. I am convinced that the law and technology } \\
\text { advancement are enough to safeguard me from } \\
\text { any problem on internet transaction and make me } \\
\text { feel safe to make the transaction in E-commerce site. } \\
\text { II3. Nowadays, internet has reliable and secure } \\
\text { environment for a transaction generally. }\end{array}$ & $\begin{array}{l}\text { McKnight et al. (2002), } \\
\text { He (2011) }\end{array}$ \\
\hline
\end{tabular}


Deterrence (DE)

Social Influence (SI)

Knowledge and Experience (KE)

Trust in E-vendor (T)

Word of Mouth Intention (WOM)

Purchase Intention (PI)
II4. I feel most of internet providers will take action appropriate with the needs of E-commerce customers. II5. I feel secure and safe to make a transaction using E-commerce site on internet because the internet providers keep their promises and obligations to the customers.

II6. I feel most of internet providers give their best service to serve the E-commerce users.

DE1. If E-commerce site where I purchase a product attempts to decept or perform a criminal action to me, I believe there will be a punishment for the seller.

DE2. Seller will not dare to have negative intention to

customers due to compensating punishment.

DE3. There are legal laws that safeguards and protects me for online transaction.

SI1. I feel a recommendation from a friend about

an E-commerce site is an honest opinion in general.

SI2. I fell a recommendation from a friend about

an E-commerce site is reliable to help me taking decision

for making online transaction.

SI3. I feel a review and rate from a friend about

an E-commerce site is honest.

SI4. I feel a review and rate from a friend about

an E-commerce site is reliable to help me taking decision for making online transaction.

SI5. I feel my friends in online forum or communities give honest opinion about an E-commerce site in general.

SI6. I feel my friends in online forum or communities are reliable to help me taking decision for making online transaction on E-commerce site.

KE1. Generally, I know well E-commerce site where I purchase online a product.

KE2. I have ever made a transaction in E-commerce site previously to purchase a product.

KE3. I know how to search a

product in E-commerce site.

KE4. I know how to make a

transaction in E-commerce site.

T1. E-commerce site I

choose is trust-worthy site.

T2. I trust to manager of E-commerce site I choose to maintain its attraction for the customers.

T3. I trust to manager of E-commerce site I choose to keep the promises to the customers. For example, on time product delivery and good product delivery.

T4. I trust the information given by

E-commerce site I choose.

WM1. I will tell positive things about

E-commerce site I choose to others

WM2. I will give the information I get from

E-commerce site I choose to others.

WM3. I will recommend E-commerce site

I choose to my friends or others.

PI1. I will purchase a product

on E-commerce site I choose.

He (2011),

D'Ambra and Xiao (2010),

Kim et al. (2008)

Kim and Park (2012)

Kim et al. (2008),

Hajli (2012b)

Kim and Park (2012)

PI2. If I am given another chance, I will consider purchasing a product on E-commerce

site I choose in another time.

PI3. I will purchase again a product in the near

time from E-commerce site I choose.
Kim et al. (2008),

Hajli (2012a)
Kim and Park (2012), 